for its Management Centre, which received special praise from UGC. It is also determined to maintain a biology presence, possibly by means of a new biotechnology unit. But staff of the existing biology department have refused to examine that plan on the grounds that it would probably involve abandoning the university's established expertise in applied biology and also lead to redundancies.

Dr Richard Etheridge, a senior lecturer in production technology at Aston and a member of the AUT national executive, says that the university staff feel that the vice-chancellor is imposing redundancies with unseemly haste. The Department of Employment was notified of the proposals (as required by employment law) on 18

\section{Object lesson Brussels}

In an unusual demonstration of its powers, the European Commission has questioned West Germany's second energy research programme, which is suspected of contravening EEC's rules on competition. The West German government has six weeks in which to reply.

The programme in question, which covers the period up to 1985 and costs DM13,465 million ( $£ 3,370$ million), was in fact approved last year and is already operating. Nevertheless, the Commission complains that it was not informed in due time about either this programme or the last one and points out that the programme is a form of state aid and so is subject to the Commission's approval.

In its letter, the Commission declares that it wants to examine in greater detail the extent to which the programme fits in with the Community's energy policy aims. The fact that much of the money will be set aside for large-scale projects, particularly in fields such as fastbreeder technology, largely carried out in Germany by private companies, leads the Commission to question whether or not the aid is leading to a distortion of competition within the Community. And second, the Commission is concerned about whether only German companies and not, say, the foreign subsidiaries of companies from other parts of EEC, will be able to take advantage of the loans and subsidies.

This is the first time that the Commission has raised objections to a national research programme and its action is being interpreted in Brussels as a sign that research programmes should not be used by national governments as a discreet form of industrial featherbedding. If the Commission is not satisfied with the reply from Bonn, and is successful in pursuing its action, a similar letter might soon be on its way to Paris.
November, and redundancy notices could be issued as early as 22 December. Several attempts by academic staff at the most recent meeting of the university senate to introduce motions urging reconsideration or delay were blocked by the vicechancellor on the grounds that these were not procedural matters.

The issue is certain to be raised again at the next meeting of the university council on 14 December. AUT is planning to lobby council members on that day, urging them to reconsider, and has threatened to tell its members elsewhere to boycott the university, depriving it of external examiners and putting existing procedures for the award of degrees in hazard.

Tim Beardsley

\title{
Spina bifida
}

\section{Controversy over tests continues}

Heart-searching and a little politicking about the UK Medical Research Council's proposed controlled trial of the utility of folic acid and other vitamin supplements as a prohylactic of spina bifida continues, fanned by the appearance of a blank space in last week's edition (see Nature 25 November, pp.302 and 310). What follows is an account of the origin and the course of this controversy.

The immediate stimulus of present interest in a controlled study of folic acid supplementation appears to have been the publication in February 1980 (Lancet i, 339) by Professor R.W. Smithells of the University of Leeds and seven collaborators of an article entitled "Possible prevention of neural-tube defects by preconceptional vitamin supplementation',. That reported on a study in which women who had previously given birth to a spina bifida child were offered a vitamin preparation containing folic acid. This report appears to have prompted the UK Department of Health to enquire, in 1980, of the Medical Research Council whether a controlled study of the efficacy of folic acid would be feasible and desirable.

Spina bifida results from the incomplete closure of the neural tube in the early stages of embryonic development, and is thought to date from 15 to 20 days after conception. The other principal neural tube defect in human beings is anencephalus. Animal models for the study of neural tube defects, among which the curly tailed mouse stands out, have not so far provided a clear picture of the mechanism by which the neural tube is closed in normal development, although they do clearly show an interaction between genetic and environmental factors in the causation of neural tube defects (see Morriss, G. Nature 284, 121; 1980).

That a dietary deficiency of some kind may be involved in the occurrence of neural tube defects in human births is suggested by the correlation between the incidence of the defects and the social class of the mothers concerned. (The incidence is greater among less prosperous families.) Another pointer of the same kind is the increased incidence of defective births among children conceived in the late winter and early spring.

The geographical variation of the incidence of these defects is, however, harder to account for. In the British Isles, the incidence of both defects is greatest in the west (Ulster and the Republic of Ireland), amounting to 9 per 1,000 in Belfast, 7 per 1,000 in South Wales, 4 per 1,000 in Birmingham (central England) and 2 per 1,000 in south-east England. By contrast, in France the incidence of the defects is less than 1 per 1,000 , while the defects are almost unknown among some of the poorest populations of the world. In North America, the incidence of the defects appears to decrease from a maximum on the east coast of about 2 per 1,000 to less than half as much on the west coast. There appears to be a puzzling cyclical variation of incidence in the United Kingdom with a periodicity of twenty years or so.

That genetic factors influence the occurrence of neural tube defects is borne out, for example, by studies in South Wales in the $1960 \mathrm{~s}$. In one survey (Carter, C.O. et al. J. med Genet. 5, 81; 1968), 5.2 per cent of the siblings of an affected mother were found to produce neural tube defective children, compared with the general incidence of 0.77 per cent in the population as a whole. The risk of neural tube malformations is, puzzlingly, greater among first births and twice as great among females as among male children. One epidemiologist said this week that there can be no other congenital malformation whose incidence provide so many clues but whose causation is still in doubt.

The notion that a deficiency of folic acid may be partly responsible appears to stem from measurements by Smithells and his colleagues suggesting that red-cell folic acid and leukocyte ascorbic acid (vitamin C) might be deficient in mothers giving birth to defective children. These measurements led to Smithells's clinical trial of the efficacy of vitamin supplements including folic acid in the prevention of recurrences of neural-tube defective births.

Women who had previously given birth to spina bifida children were recruited to the study principally from genetic counselling clinics, but also by referral from general practitioners, and were offered a course of treatment with a multivitamin preparation containing folic acid. Among those who accepted, 137 gave birth within the period of the study, as did 187 of those who were found already to have become pregnant again (or who declined). In the first report of the study, among 140 children born to the mothers supplemented with folic acid, there was only one neural tube defect. But there were 